\title{
PELAKSANAAN TUGAS KEPOLISIAN DALAM PENANGGULANGAN KONFLIK SOSIAL DI WILAYAH POLDA SUMUT
}

\author{
Oleh: \\ Lestari Victoria Sinaga \\ Universitas Darma Agung, Medan \\ E-Mail : \\ missthary35@gmail.com
}

\begin{abstract}
Aspect of social conflict that needs to be considered is violence arising from social conflict. Conflict management aims at preventing how violence does not occur and conflict parties can handle and resolve their conflicts without using violence. Government Regulation Number 2 Year 2015 concerning Act Implementing Regulation Number 72012 concerning Handling Social Conflict was made to protect and provide a more optimal sense of community security. Governmentregions in preventing conflicts optimizepeaceful dispute resolution through deliberation for consensus and can involve participation of the society.
\end{abstract}

Keywords: Social Conflict, Social Conflicts Settlement

\section{PENDAHULUAN}

\section{A. Latar Belakang}

Sejumlah polisi disiagakan pengamanan di DKI untuk mengantisipasi segala macam potensi gangguan kamtibmas, dimulai dari akhir putusan Mahkamah Konstitusi mengenai sidang gugatan hasil Pilpres 2019.

Potensi konflik yang bersumber dari akar masalah yang beragam tersebut seharusnya perlu dideteksi dan diidentifikasi lebih dini sehingga dapat dilakukan upaya antisipasi dan pencegahannya agar potensi konfliktidak berkembang menjadi konflik terbuka.

\section{Segitiga Konflik:}

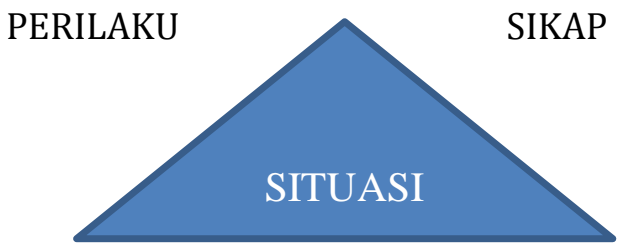

Segitiga konflik adalah salah satu cara yang berguna dan popular untuk menggambarkan kompleksitas konflik. $^{1}$ Segitiga tersebut terdiri dari situasi konflik, sikap konflik dan perilaku konflik:

- Situasi konflik: ketidakselarasan tujuan, kebutuhan dan kepentingan berbagai pihak;

- Sikap: menyangkut aspek-aspek kontruksi musuh, dan emosi, sumber-sumber musuh diantaranya ketegangan pribadi, frustasi kelompok.

- Perilaku: kegiatan, perkataan, dan perilaku actual yang terporalisasi dan merusak dari pihak-pihak yang bertikai.

Permainan Peran Negoisasi dalam pembangunan Gereja HKBP Depok misalnya, menerapkan keterampilan mendengar pasif, aktif yakni tawar menawar dan pemecahan masalah. Dalam usaha pencegahan konflik seperti 
pemerintahan daerah, organisasi internasional, tokoh agama, polisi dan wakil-wakil dari berbagai kelompok masyarakat yang beraneka ragam, etnis, suku, gender. Polisi dapat menjadi katalis atau pemangkin pencegahan konflik.

Community policing yang diterjemahkan dalam perpolisian masyarakat yang berorientasi masyarajat berasal dari COP (community oriented policing) dan POP (problem oriented policing). Perpolisian masyarakat inilah yang menjadi keprihatinan polisi dan masyarakat dalam meredam kejadian yang bagian dari tupoksi polisi.

Unjuk rasa atau demonstrasi ini biasanya dilakukan untuk mendukung atau menolak suatu kebijakan yang dikeluarkan oleh pemerintah maupun swasta, menurut Pasal 1 angka 3 pada Undang-undang No. 9 tahun 1998 tentang Kemerdekaan Menyampaikan Pendapat di Muka Umum, disebutkan bahwa pengertian unjuk rasa adalah "kegiatan yang dilakukan oleh seseorang atau lebih untuk mengeluarkan pikiran dengan lisan, tulisan dan sebagainya secara demonstratif di muka umum.

Oleh karenanya Undang-undang Nomor 7 Tahun 2012 tentang Penanganan Konflik Sosial mengamanatkan dilakukanya upaya penanganan konflik sosial yang sistematis, komprehensif, integratif, efektif, efisien, akuntabel, dan transparan.

Upaya-upaya penyelesaian perselisihan atau konflik sendiri di atur di dalam Undang-undang Penanganan Konflik Sosial meliputi :

1. Penghentian kekerasan fisik;

2. Penetapan status keadaan konflik;

3. Tindakan darurat penyelematan dan perlindungan korban;

4. Bantuan penggunaan dan pengerahan kekuatan TNI.
Upaya tersebut dimulai dari identifikasi potensi konflik, pencegahan konflik, pengehentian konflik, dan pemulihan pascakonflik, sehingga langkah-langkah Polri dalam penanganan konflik mengacu pada ketentuan perundang-undangan.

Penanganan Konflik adalah serangkaian kegiatan yang dilakukan secara sistematis dan terencana dalam situasi dan peristwa baik sebelum, pada saat maupun sesudah terjadi konflik yang mencakup pencegahan konflik, penghentian konflik dan pemulihan pascakonflik.

Konflik berasal dari bahasa latin, configere yang berarti saling memukul. Secara sosiologis, konflik diartikan sebagai suatu proses sosial antara dua orang atau lebih dimana salah satu pihak berusaha menyingkirkan orang lain dengan membuatnya tidak berdaya.

Contoh konflik sosial di Indonesia yang sudah pernah terjadi yakni:

1. Konflik suku di Sampit, konflik yang sangat fenomenal sekali dalam masyarakat yang pernah terjadi di Kalimantan Baratantara Suku Madura (pendatang) dengan Suku dayak (suku asli Kalimantan);

2. Konflik suku di Lampung, terjadi karena kesenjangan sosial ekonomi antara masyarakat asli dan masyarakat pendatang;

3. Konflik sosial di Aceh, penyebab dilatar belakangi bahwa Aceh memiliki cadangan minyak bumi terbesar di Indonesia dibandingkan Minyak bumi di Arab Saudi, sebab itu dulu Aceh berkeputusan untuk membuat kemerdekaan sendiri dan berpisah dari NKRI akhirnya dilakukan perundingan kerjasama menekan konflik sosial yang ada di Aceh;

4. Konflik Sosial di Yogyakarta, banyaknya tempat belajar di 
Yogyakarta yang diminati masyarakat Papua Barat, dimana Papua Barat dulu pernah mau memerdekakan diri, sebab itu dilakukan pengusiran mashasiswa pro kemerdekaan Papua Barat dari wilayah Jawa.

5. Konflik sosial di Lampung Tengah, perilaku kasar do Kampung Jawa yang membakar rumah mereka serta melakukan pembunuhan.

6. Konflik sosial di Nusa Tenggara Timur (NTT), masuk kedalam jenis konflik horisontal di Desa Wulubolong dengan Desa Lohayonh dengan latar belakang berebut kekayaan alam di wilayah perbatasan desa.

7. Konflik sosial di Ambon, adanya kesenjangan sosial masyarakat Islam dengan Katolik pada tahun 1998.

Dari beberapa contoh konflik sosial tersebut terjadi konflik disebabkan munculnya kesenjangan sosial atas hubungan sosial dalam kehidupan sehari-hari. Dalam keadaan tersebut ada korban yang kerugian material, jiwa dan untuk itulah dikenal cara penyelesaia konflik didalam masyarakat.

Tindakan tegas dan terukur adalah serangkaian tindakan kepolisian yang dilakukan oleh anggota Polri baik perorangan maupun dalam ikatan kesatuan secara profesional, proporsional dan tanpa ragu-ragu serta sesuai peraturan perundang-undangan.

Tindakan Kepolisian adalah upaya paksa dan atau tindakan lain yang dilakukan secara bertanggungjawaba menurut hukum yang berlaku untuk mencegah, menghambat, atau menghentikan anarki atau pelaku kejahatan lainnya yang mengancam keselamatan, atau membahayakan jiwa raga, harta benda atau kehormatan kesusilaan guna mewujudkan tertib dan tegaknya hukum serta terbinanya ketentraman masyarakat.

Peraturan Kepala Kepolisian

Negara Republik Indonesia Nomor 8 Tahun 2013 tentang Teknis Penanganan Konflik Sosial, mengidentifikasi potensi konflik melalui langkah inventarisasi, penelitian dan penentuan prioritas penangannya. Inventarisasi potensi konflik merupakan kegiatan yang dilakukan dengan mengumpulkan, mendatakan dan mengelompokan berbagai potensi konflik yang dapat bersumber dari: ${ }^{2}$

Permasalahan yang berkaitan dengan politik, ekonomi, dan sosial budaya, antara lain berupa:

1. Perselisihan dalam pelaksanaan pemilu Legislatif, pemilu Presiden/Wapres, dan/atau Pemilukada;

2. Konflik inter/antar partai politik, dan organisasi masa yang berafilisiasi/sayap;

3. Kebijakan pemerintah antara lain atas kenaikan harga BBM dan/atau Sembako;

4. Peraturan perundang-undangan yang menimbulkan reaksi penolakan dari masyarakat, seperti pemerkaran wilayah;

5. Perselisihan perburuhan dan hubungan industrial;

6. Permasalahan transport;

7. Masalah irigasi atau perebutan sumber air;

8. Penggusuran tempat tinggal atau tempat usaha (relokasi);

9. Kesenjangan antarkelompok/kecemburuan sosial.

Perseteruan antar umat atau intraumat beragama, antarsuku, dan antarentnik, antara lain berupa: 
a. Reaksi atas pendirian rumah ibadah atau rumah/bangunan yang dijadikan tempat ibadah;

b. Perbedaan aliran intraumat dan/atau antarumat beragama;

c. Penistaan agama; dan

d. Konflik antarsuku/etnik, ras, dan golongan; dan

e. Perkelahian antarwarga/kelompok/pel ajar;

f. Sengketa batas wilayah desa, kabupaten/kota, dan/atau provinsi, antara lain: pemekaran wilayah; klaim atau wilayah tertentu; batas wilayah yang tidak jelas.

\section{B. Perumusan Masalah}

Dirumuskan inti persoalan yang akan dibahas dalam penelitian ini adalah:

a. Bagaimanakah Pengaturan Hukum Penanganan konflik Sosial menurut Peraturan Perundang-undangan?

b. Bagaimanakah pelaksanaan Tugas kepolisian dalam Penanganan Konflik Sosial di wilayah Hukum Poldasu?

\section{Tujuan Penelitian}

Adapun tujuan dari penelitian ini dilakukan adalah:

a. Untuk mengetahui dan memahami ketentuan hukum penanganan konflik sosial menurut peraturan perundangundangan.

b. Untuk mengetahui dan menganalisis Pelaksanaan Tugas Kepolisian dalam Penanganan Konflik Sosial di wilayah hukum Poldasu.

\section{Manfaat Penulisan}

Penulis diharapkan dapat memberikan manfaat secara teoritis maupun praktis.

\section{METODE PELAKSANAAN}

Penelitian ini menggunakan metode penelitian normatif. Penelitian normatif yuridis/penelitian doktrinal yaitu penelitian dilakukan melalui perpustakaan (library research). Sifat dari penelitian adalah deskriptif .

Data yang digunakan dalam penelitian ini adalah sekunder yang terdiri dari bahan primer berupa peraturan perundang - undangan yang berkaitan denganTugas kepolisian dalam Penanganan Konflik Sosial di wilayah Hukum Poldasu.

Data-data yang sudah dikumpulkan selanjutnya akan dianalisis secara kualitatif yakni Tugas kepolisian dalam Penanganan Konflik Sosial di wilayah Hukum Poldasu, kemudian membuat sistematika dari pasal-pasal, sehingga akan menghasilkan klasifikasi sesuai dengan permasalahan yang dibahas dalam penelitian ini. Data-data kemudian dikemukakan dalam bentuk uraian secara sistematis untuk menjelaskan hubungan antar data, sehingga selain menggambarkan dan mengungkapkan dasar hukumnya juga dapat memberikan solusi terhadap permasalahan yang dimaksud.

\section{HASIL PENELITIAN DAN PEMBAHASAN \\ A. Ketentuan Hukum Yang Mengatur tentang Penanganan Konflik Sosial}

Adapun beberapa peraturan yang mengatur tentang penanganan konflik social oleh Kepolisian adalah: 
1. Berdasarkan Peraturan Kapolri Nomor 9 Tahun 2008 tentang Tata Cara Penyelenggaraan, Pelayanan, Pengamanan dan Penanganan Perkara Penyampaian Pendapat di Muka Umum;

2. Perkap Nomor 01 Tahun 2009 tentang Penggunaan Kekuatan dan Tindakan Kepolisian

3. Peraturan Kapolri Nomor 16 Tahun 2006 tentang Pedoman Pengendalian Massa (Protap Dalmas)

Disini dalam penindakan hukum sesuai protap, kata memukul berlebihan atau tidak berlebihan harus dilihat. Indikator memukul secara berlebihan timbul jika nyatanya ada luka serius, atau bahkan kematian. Sedangkan jika tidak berlebihan indikatornya adalah kalau dipukul tidak ada perlawanan polisi hanya melumpuhkan orang atau massa tersebut diluar prosedur.

Ketika ada penyerangan polisi juga harus melihat kondisi mereka apakah terancam atau tidak terancam. Jika ada penyerangan, polisi hanya bersikap defensive tapi kalau sudah ada pengancaman terhadap nyawa polisi tersebut atau rekan polisinya, maka polisi sudah bisa menggunakan kekerasan untuk melawan sesuai kekerasan dalam prosedur. Dimana kekerasan dalam prosedur adalah kekerasan yang digunakan polisi dalam situasi tertentu di mana kondisi mereka terancam. Dalam kekuatan polisi dan lawannya pun harus seimbang. Polisi bersenjata dan lwan tidak, atau massa sudah lemah dan tanpa senjata tetap dipukuli itu baru kesalahan yang hakikik, kekerasan harus ada ukurannya dan tidak boleh berlebihan.
Pada ayat 2 disebutkan bahwa Ditsabhara menyelenggarakan kegiatan, Turwajali, bantuan satwa, pengamanan unjuk rasa dan pengendalian massa.

Pertimbangandari dikeluarkannya peraturan Kapolri Nomor 16 Tahun 2006 ini adalah karena penyampaian pendapat di muka umum adalah hak setiap warga Negara untuk menyampaikan pikiran dengan lisan/tulisan secara bebas dan bertanggung jawab sesuai dengan ketentuan perundang-undangan yang berlaku dan Negara dalam hal ini yang diwakili oleh Polri wajib memberikan pelayanan dan pengendalian massa terhadap aksi penyampaian pendapat dimuka umum tersebut atau yang disebut dengan kegiatan unjuk rasa, Baik yang dilakukan di di jalan raya, di gedung/ bangunan penting dan di lapangan/ lahan terbuka, serta yang dilakukan dalam kondisi secara tertib atau tidak tertib.

Tugas dan wewenang polisi dalam memelihara keamanan dan ketertiban masyarakat pada tugas dan wewenang tersebut dapat dikaitkan dengan Pasal 13 ayat (3) UU No. 9 tahun 1998 yang menyatakan bahwa "dalam penyampaian pendapat di muka umum, Polri bertanggung jawab menyelenggarakan pengamanan untuk menjamin keamanan dan ketertiban umum sesuai dengan prosedur yang berlaku

\section{B. Peran Polisi dalam Penanganan Konflik}

Dalam tubuh kepolisian ada tugasnya menjaga ketertiban yaitu Samapta/Brimob, Reskrim, dan Intelkam. Sesuai dengan Protap 09 tentang penggunaan kekerasan kepolisian mengambil sikap represif bila diperlukan dengan catatan tetap menghindari terjadinya pelanggaran HAM. 
Jika kepolisian dapat meminta bantuan kekuatan dari aparat TNI seperti Pasal 41 angka 1 UU No 2 Tahun 2002.

Adapun tahap-tahap penanganan konflik social:

1. Tahapan situasi tertib (Hijau)

Tahapan tertib adalah tahapan dimana kegiatan unjuk rasa masih berjalan aman, tidak ada kegiatan yang mengarah pada kegiatan tidak tertib. Dalam situasi tertib diturunkan pasukan dalmas awal. Dalmas awal adalah satuan Dalmas yang tidak dilengkapi dengan perlengkapan khusus kepolisian digerakkan dalam menghadapi kondisi massa masih tertib dan teratur ( situasi hijau).

Pada situasi tertib pasukan Dalmas melakukan pengawalan dan pengamanan kepada pengunjuk rasa sambil terus memberikan himbauan kepada pengunjuk rasa. Redaksional Himbauan yang dimaksud adalah : Kepada saudara-saudara pengunjuk rasa, kami dari jajaran Kepolisian memohon dengan sangat kepada saudara - saudaraku :

a. Agar saudara-saudara dapat menjaga ketertiban dan keamanan, jangan melakukan pelanggaraan hokum

b. Sampaikan aspirasi dan pendapat saudara-saudara secara sopan dan baik. Saudara-saudara jangan terprovokasi oleh tindakan tindakan orang yang tidak bertanggung jawab

c. Jangan menyusahkan anggota masyarakat lainnya

d. Jaga kehormatan dan martabat kita sebagai anggota masyarakat
Dalam pelaksanaan unjuk rasa, pihak kepolisian melakukan rekaman jalannya unjuk rasa mengunakan video kamera baik bersifat umum maupun khusus, selama unjuk rasa berlangsung. Keberadaan pasukan Dalmas yang juga merupakan manusia biasa, tidak mungkin memantau kagiatan yang dilakukan pangunjuk rasa secara perorangan. Jadi pemantauan dilakukan dengan menggunakan kamera video yang dilakukan oleh kapolisian dari fungsi Intelkam. Tujuan pemantauan dengan kamera ini juga berguna dalam penegakan hukum apabila ada kegiatan pelanggaran hukum yang dilakukan oleh orang tertentu.

$$
\text { Pada tahapan ini pihak }
$$
kepolisian melakukan negosiasi melalui negosiator dengan korlap pengunjuk rasa. Negosiator adalah anggota Polri yang melaksanakan perundingan melalui tawar menawar dengan massa pengunjuk rasa untuk mendapatkan kesepakatan bersama. Negosiator berada di depan pasukan Dalmas awal melakukan perundingan atau negosiasi dengan korlap untuk menampung aspirasi.

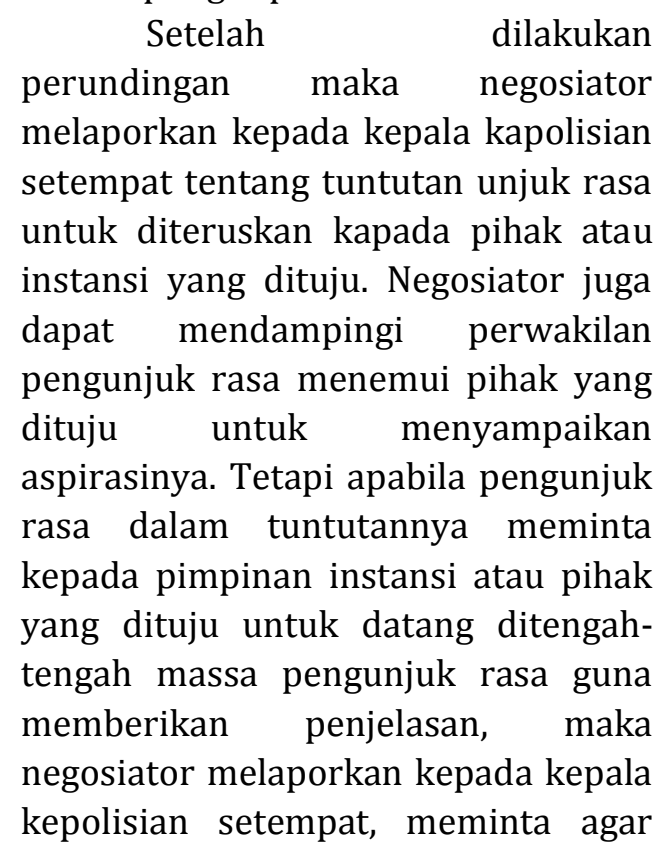


pimpinan instansi atau pihak yang dituju dapat memberikan penjelasan ditengah tengah pengunjuk rasa. Dalam memberikan penjelasan, pimpinan instansi atau pihak yang dituju terus didampingi oleh negosiator dan kepala kepolisian setempat.

Setiap komandan peleton (Dan Ton) atau komandan kompi (Dan Ki) terus melaporkan setiap perkembangan situasi kepada kepala kapolisian setempat dalam hal ini merupakan pemegang kendali taktis. Kendali taktis adalah pengendalian oleh Kapolsek, Kapolsekta,

Kapolsek Metro, Kapolres, Kapolresta, Kapolres Metro, Kapoltabes, Kalpolwil, Kapolwiltabes, Kapolda yang berwenang mengatur segala tindakan pasukan dilapangan pada lokasi unjuk rasa. Apabila situasi meningkat dari tertib (hijau) kepada situasi tidak tertib (kuning), maka dilakukan lapis ganti dengan Dalmas lanjut. Lapis ganti adalah kegiatan peralihan dari satuan dalmas awal ke dalmas lanjutan.

\section{b. Tahapan Situasi Tidak Tertib (Kuning) Pada tahapan ini negosiator} masih terus melakuan negosiasi dengan korlap pengunjuk rasa semaksimal mungkin, meski keadaan sudah tidak tertib (kuning). Situasi tidak tertib adalah situasi dimana para pengunjuk rasa sudah mulai melakukan perbuatan perbuatan yang menggangu ketertiban dan keamanan sekitar lokasi unjuk rasa, aksi tetrikal dan aksi sejenisnya yang menyusahkan anggota masyarakat lainnya.

Misalnya tindakan membakar sesuatu pada jalan raya, tidur-tiduran di jalan sehingga mengganggu para pengguna jalan. Maka dalam hal ini pasukan Dalmas lanjutan membantu mengangkat dan memindahkan ke tempat yang netral dan atau lebih aman dengan cara persuasif dan edukatif. Dalmas lanjutan adalah satuan dalmas yang dilengkapi dengan alat-alat perlengkapan khusus kepolisian, digerakkan dalam menghadapi kondisi massa sudah tidak tertib (kuning).

Dalam melakukan lapis ganti dari dalmas awal kepada dalmas lanjut maka polisi dapat menggunakan unit satwa dengan formasi bersaf di depan dalmas awal untuk melindungi saat melakukan proses lapis ganti. Lapis ganti adalah kegiatan peralihan dari dalmas awal ke dalmas lanjut.

Apabila eskalasi meningkat dan atau massa melempari petugas dengan benda keras, maka Dalmas lanjut melakukan sikap berlindung selanjutnya kepala kepolisian setempat memberikan himbauan kepada Danton atau Danki Dalmas lanjut untuk melakukan tindakan hukum sebagai berikut :

Kendaraan taktis pengurai massa bergerak maju melakukan tindakan mengurai massa, bersamaan dengan itu dalmas lanjut maju dengan melakukan pendorongan massa.

1. Petugas pemadam api dapat melakukan pemadaman api, pemadaman ban, spanduk, bendera dan alat peraga lainnya.

2. Melakukan pelemparan dan penembakan gas air mata.

Pada situasi tidak tertib (kuning) pasukan dalmas lanjutan melakukan pengamanan ataupun evakuasi terhadap VIP atau pejabat penting lainnya dengan menggunakan kendaraan taktis penyelamat. Setiap Danton atau Danki terus melaporkan setiap perkembangan situasi kepada kepala kepolisian setempat. Dan 
apabila situasi semakin meningkat maka kepala kepolisian setempat melaporkan kepada Kapolres selaku pengendali umum agar dilakukan lintas ganti dengan Detasemen atau Kompi Penanggulangan Huru Hara (PHH) Brigade Mobil (Brimob).

c. Tahapan Melanggar Hukum (Merah) Situasi melanggar hukum adalah situasi dimana pada saat kegiatan unjuk rasa telah terjadi perbuatan-perbuatan yang melanggar hukum oleh para pengunjuk rasa. Misalnya terjadi pencurian, pengrusakkan kepada benda milik umum atau masyarakat sekitar, intimidasi ataupun perbuatan pidana lainnya. Pada situasi melanggar hukum kendali dipegang oleh Kapolres selaku pengendali umum, setelah adanya pemberitahuan dari kepala kepolisian setempat tentang situasi melanggar hukum.

\section{KESIMPULAN DAN SARAN}

\section{Kesimpulan}

A Pengaturan Penanganan konflik sosial diatur dalam UU No 7 Tahun 2012 tentang Penanganan Konflik Sosial, Perkap No 16 Tahun 2006 tentang Penggunaan Kekuatan dalam Tindakan Kepolisian, Protap Nomor/1/X/2010 tentang Penanggulangan Anarki.

B Peran Polisi dalam Penanganan Konflik Sosial merupakan peran sentral sebagai alat negara yang bertugas memelihara keamanan, dan ketertiban masyarakat yang dimulai dari Bhabinkamtibmas, Pasukan Sabhara dan apabila berada di daerah rawan (merah) dimulai oleh pasukan Huru Hara Brimob.

\section{Saran}

A Seharusnya dalam mencegah konflik sosial perlu diupayakan koordinasi dengan para tokoh adat serta tokoh-tokoh masyarakat mencegah unjuk rasa yang besar.

B Seharusnya, polisi menjalankan standar operasional pelaksana unjuk rasa sesuai dengan Perkap dan tidak menanggapi emosi pada masyarakat yang sehingga tidak dipandang jelek.

\section{DAFTAR PUSTAKA}

\section{A. Buku-Buku}

Firman Noor, Kompleksitas Konflik Lampung", Kompas, 3 Nopember 2012.

Maria Farida indriati, Ilmu Perundang-undangan Proses dan Teknik Pembentukannya, Jakarta : Kanisius, 2006

Marzuki, Peter Mahmud, Penelitian Hukum, Jakarta: Kencana Prenada Media Grup, 2010

Mohammad Arief Pranoto, Peran Kepolisian dalam Penanganan Konflik Sosial di Daerah Yogyakarta, 2013

\section{B. Peraturan Perundang-undangan}

UU No 7 Tahun 2012 tentang

Pokok-pokok Kepolisian RI.

Peraturan kepala Kepolisian

Nomor 16 Tahun 2006 tentang Penggunaan Kekuatan dalam Tindakan Kepolisian.

Peraturan Kapolri Nomor 1 Tahun 2009 tentang Penggunaan kekuatan dalam Tindakan Kepolisian

Peraturan Pelaksana No 2 Tahun 2015 tentang Peraturan Pelaksanaan Undang-undang Nomor 7 tahun 2012 tentang Penanganan Konflik Sosial.

Permendagri No 42 Tahun 2015 tentang Pelaksanaan Koordinasi Penanganan Konflik Sosial 


\section{Internet}

https://media.neliti.com/media/publicat ions/797-ID-manajemen-konflik-untukpolisi.pdf

Info Singkat, Peran Polisi dalam Penanganan Konflik Sosial balinuraga di Lampung Selatan, Volume IV No 21/I/P3DI/November / 2012 diakses dalam website http://berkas.dpr.go.id/puslit/files/info singkat/Info\%20Singkat-IV-21-I-P3DINovember-2012-33.pdf pada tanggal 26 Juni 2019. 